\title{
ANALISIS KONFLIK SUMBERDAYA HUTAN DI KAWASAN KONSERVASI
}

\author{
Analysis of Resource Forest Conflict in Conservation Area \\ Ina Marina ${ }^{*}$ dan Arya Hadi Dharmawan \\ Departemen Sains Komunikasi dan Pengembangan Masyarakat, Fakultas Ekologi Manusia, IPB \\ *)Email : inamarina@yahoo.com
}

Diterima 11 Februari 2011 / Disetujui 30 Maret 2011

\begin{abstract}
This study focused on the history of natural resource conflict, the actors who involved in conflicts in Gunung Halimun-Salak National Park and the forms of conflict resolutions that has been done. The approach in this study is a qualitative approach with a case study methode. The data obtained with depth interview techniques, observation, and documentation. This study was conducted in Kampung Sinar Resmi, that belongs to the Kasepuhan Sinar Resmi community. This location is a place where community's cultivating land overlap with the claim of Gunung Halimun-Salak National Park, thus causing a lack of clear boundaries and result in forest resource conflicts. Forest resource conflicts are caused by four different conflicts sources, namely differences in perceptions, different values, different interests, and differences in recognition of ownership rights. The forms of conflict resolution that has been done is negotiation, but doesn't reach the agreement.
\end{abstract}

Keywords: conflict, Gunung Halimun-Salak National Park, forest resource conflict

\section{PENDAHULUAN}

\section{Latar Belakang}

Sumberdaya alam hayati adalah unsur-unsur hayati di alam yang terdiri dari sumberdaya alam nabati (tumbuhan) dan sumberdaya alam hewani (satwa) yang bersama dengan unsur nonhayati di sekitarnya secara keseluruhan membentuk ekosistem (Mensesneg, 1990). Budimanta (2007) mengungkapkan bahwa keberadaan sumberdaya alam yang penting bagi kehidupan manusia, menjadikan kompleksitas hubungan antara berbagai pihak yang memiliki kepentingan dalam pengelolaan sumberdaya alam.

Sumberdaya alam bagi masyarakat sudah menjadi bagian dari kehidupannya, baik dalam bidang sosial, ekonomi, maupun politik. Pemerintah kemudian menetapkan UU No. 5 Tahun 1990 mengenai Konservasi Sumberdaya Alam dan Ekosistemnya, mengingat keberadaan sumberdaya alam yang tidak dapat tergantikan dan penting bagi kehidupan manusia. Melalui UU No.5 Tahun 1990, pemerintah juga menetapkan kawasan konservasi pada suatu wilayah yang memiliki keanekaragaman hayati yang khas dan perlu dikelola dan dimanfaatkan secara lestari. Kawasan konservasi memiliki fungsi sebagai sistem penyangga kehidupan, pengawetan keanekaragaman satwa dan tumbuhan, serta pemanfaatan secara lestari sumberdaya alam. Kawasan konservasi dibedakan menjadi kawasan suaka alam dan kawasan pelestarian alam. Taman nasional merupakan salah bentuk dari kawasan pelestarian alam.
Kawasaan Gunung Halimun dan Gunung Salak merupakan kesatuan hamparan hutan dataran rendah dan pegunungan yang mempunyai keanekaragaman hayati yang tinggi, sumber mata air bagi kepentingan kehidupan masyarakat disekitarnya yang perlu dilindungi dan dilestarikan (Menhut RI, 2003). Pemerintah kemudian menetapkan kawasan Gunung Halimun dan Gunung Salak seluas 113.357 hektar melalui Surat Keputusan Menteri Kehutanan No. 175 Tahun 2003 dengan nama Taman Nasional Gunung Halimun-Salak. Kawasan Taman Nasional Gunung Halimun-Salak terletak di tiga Kabupaten (Bogor, Sukabumi dan Lebak) dan dua Provinsi (Jawa Barat dan Banten). Kawasan Taman Nasional Gunung Halimun-Salak didiami juga oleh komunitas-komunitas adat yang memiliki relasi yang kuat terhadap alam, yaitu masyarakat adat Kasepuhan.

Sejak ratusan tahun lalu, masyarakat adat Kasepuhan telah melakukan pengelolaan hutan sesuai dengan peraturan adat. Masyarakat adat mengelola hutan berdasarkan dengan jenis-jenis hutan yang telah dikategorikan oleh adat. Terdapat tiga jenis hutan yang dikategorikan oleh adat, yaitu Leuweung tutupan (hutan tutupan), Leuweung titipan (hutan titipan), dan Leuweung bukaan (hutan bukaan). Pengelolaan ketiga jenis hutan ini diatur oleh adat, yang diwakilkan oleh ketua adat (Abah).

Secara tiba-tiba, pemerintah mengklaim kawasan hutan milik masyarakat adat Kasepuhan sebagai bagian dari taman nasional, dan dilakukan secara sepihak tanpa sepengetahuan masyarakat Kasepuhan dan mengancam kehidupan masyarakat. Keberadaan Taman Nasional 
Gunung Halimun-Salak telah meresahkan dan mengancam kehidupan masyarakat adat Kasepuhan dalam bentuk pemanfaatan hutan.

\section{Pertanyaan Penelitian}

Penelitian ini memfokuskan pada penguraian mengenai bagaimana sejarah konflik dan pihak-pihak yang terlibat dalam konflik sumberdaya alam, serta bentuk-bentuk penyelesaian yang telah dilakukan untuk meredam konflik di Taman Nasional Gunung Halimun-Salak?

\section{Tujuan Penelitian}

Penelitian ini bertujuan untuk mengetahui sejarah konflik dan pihak-pihak yang terlibat dalam konflik sumberdaya alam, serta memahami bentuk-bentuk penyelesaian yang telah dilakukan untuk meredam konflik di Taman Nasional Gunung Halimun-Salak.

\section{Metodologi Penelitian}

Peenelitian ini menggunakan pendekatan kualitatif dengan metode studi kasus. Pendekatan kualitatif dipilih peneliti karena mampu memberikan pemahaman yang mendalam dan rinci mengenai suatu peristiwa atau gejala sosial, serta mampu menggali realitas dan proses sosial maupun makna yang didasarkan pada pemahaman yang berkembang dari subjek yang diteliti (Sitorus, 1998). Metode studi kasus pada pelaksanaannya di lapangan dilakukan dengan menggunakan wawancara mendalam, pengamatan berperan serta terbatas, maupun penelusuran (analisis) data sekunder sebagai instrumennya. Strategi studi kasus yang diterapkan oleh peneliti mampu menghindari terbatasnya pemahaman yang diikat oleh suatu teori tertentu dan yang hanya berdasar pada penafsiran peneliti. Penelitian dilakukan di Kampung Sinar Resmi, Desa Sirna Resmi, Kecamatan Cisolok, Kabupaten, Jawa Barat, pada masyarakat adat Kasepuhan Sinar Resmi. Penelitian ini dianalisis mengunakan tiga jalur analisis data kualitatif yaitu reduksi data, penyajian data dan penarikan kesimpulan (Sitorus, 1998).

\section{LANDASAN TEORI}

Konflik dapat diartikan sebagai pertarungan antara dua pihak atau lebih, baik individu maupun kelompok yang biasanya disebabkan oleh perbedaan nilai, pandangan, aktivitas, status, dan kelangkaan sumberdaya alam. Pernyataan ini diperkuat oleh pernyataan Fuad dan Maskanah (2000), Ibrahim (2002) sebagaimana dikutip Ilham (2006) serta Fisher et al. (2001) yang mengungkapkan bahwa konflik muncul karena ada sasaran-sasaran yang tidak sejalan atau tidak sama. Konflik akan selalu ditemui selama manusia menjalankan peranannya di dalam kehidupan. Manusia melakukan berbagai usaha untuk memenuhi kebutuhnnya, yang dalam pelaksanaannya manusia harus melaksanakan hak dan kewajibannya. Ketika merealisasikan hak-hak manusia yang merupakan bagian dari komunal, sering terjadi benturan-benturan antara pemenuhan hak-hak tersebut. Benturan-benturan tersebut menimbulkan ketidakadilan dan memicu tumbuhnya konflik antar manusia. Menurut Tadjudin (2000), sumber konflik adalah perbedaan dan perbedaan tersebut bersifat mutlak yang artinya secara obyektif memang berbeda. Namun perbedaan tersebut hanya ada pada tingkat persepsi
(Tadjudin, 2000). Pihak lain bisa dipersepsikan memiliki sesuatu yang berbeda dan pihak lain dicurigai sebagai berbeda, meski secara obyektif sama sekali tidak terdapat perbedaan. Menurut Tadjudin (1999) perbedaan tersebut dapat terjadi pada tataran, antara lain: (1) perbedaan persepsi; (2) perbedaan pengetahuan; (3) perbedaan tatanilai; (4) perbedaan kepentingan; dan (5) perbedaan akuan hak kepemilikan (klaim). Penyebab konflik yang ditekankan oleh Fisher et al. (2001) adalah isu-isu utama yang muncul pada waktu menganalisis konflik, yaitu isu kekuasaan, budaya, identitas, gender dan hak. Isu-isu ini muncul ketika mengamati interaksi antar pihak yang bertikai, yang pada satu kesempatan tertentu akan menjadi latar belakang konflik serta berperan sebagai faktor-faktor yang mempengaruhi secara diam-diam. Konflik pengelolaan sumberdaya hutan yang sering terjadi adalah konflik antara masyarakat di dalam dan di sekitar hutan terutama hutan konservasi, dengan berbagai pihak luar yang dianggap memiliki otoritas dalam pengelolaan sumberdaya hutan, seperti pemerintah dan swasta (Ulfah, 2007).

Konflik dapat berwujud konflik tertutup (latent), mencuat (emerging), dan terbuka (manifest) seperti yang diungkapkan oleh Fuad dan Maskanah (2000). Selain itu, Fuad dan Maskanah (2000) juga membagi konflik menjadi dua jenis menurut level permasalahannya, yaitu konflik vertikal dan konflik horizontal. Dalam konflik sumberdaya alam, konflik yang terjadi dapat berwujud tertutup, mencuat, maupun terbuka, tergantung karakteristik aktor-aktor yang berselisih. Menurut level permasalahannya, konflik sumberdaya alam cenderung berwujud konflik vertikal, yang terjadi antara pemerintah dan masyarakat.

Terdapat beberapa karakteristik dari konflik seperti yang dijelaskan Hendricks (1996) sebagaimana dikutip oleh Ilham (2006), yaitu: (1) dengan meningkatnya konflik, perhatian pada konflik itu akan meningkat; (2) keinginan untuk menang meningkat seiring dengan meningkatnya keinginan pribadi; (3) orang yang menyenangkan dapat menjadi berbahaya bagi orang lain, seiring dengan meningkatnya konflik; (4) strategi manajemen konflik yang berhasil pada tingkat konflik tertentu, sering tidak efektif pada tingkat konflik yang lebih tinggi; (5) onflik dapat melampaui tahapan yang lazim; (6) seseorang dapat menjadi individu yang berbeda selama berada dalam konflik.

Konflik berubah setiap saat, melalui berbagai aktivitas, intensitas, ketegangan dan kekerasan yang berbeda. Tahap-tahap ini penting diketahui untuk membantu menganalisis berbagai dinamika dan kejadian yang berkaitan dengan masing-masing tahap konflik (Fisher et $a l ., 2001)$. Analisis dasar tahapan konflik terdiri dari lima tahap, yaitu:

1. Prakonflik. Ini merupakan periode di mana terdapat ketidaksesuaian sasaran antara dua pihak atau lebih, sehingga timbul konflik. Mungkin terdapat ketegangan hubungan di antara beberapa pihak dan/atau keinginan untuk menghindari kontak satu sama lain pada tahap ini. 
2. Konfrontasi. Pada tahap ini, konflik menjadi semakin terbuka. Jika hanya satu pihak yang merasa ada masalah, mungkin para pendukungnya mulai melakukan aksi demonstrasi atau perilaku konfrontatif lainnya.

3. Krisis. Tahap ini merupakan puncak konflik, ketegangan dan/atau kekerasan terjadi paling hebat. Komunikasi normal di antara kedua pihak kemungkinan putus. Pernyataan umum cenderung menuduh atau menentang pihak lain.

4. Akibat. Suatu krisis akan menimbulkan akibat. Satu pihak ingin menaklukan pihak lain, satu pihak mungkin menyerah atau menyerah atas desakan pihak lain. Kedua pihak mungkin setuju bernegosiasi, dengan atau tanpa bantuan perantara. Apapun keadaaannya, tingkat ketegangan konfrontasi dan kekerasan pada tahap ini agak menurun, dengan kemungkinan adanya penyelesaian.

5. Pascakonflik. Situasi diselesaikan dengan cara mengakhiri berbagai konfrontasi kekerasan, ketegangan berkurang dan hubungan mengarah normal di antara kedua pihak. Namun, jika isu-isu dan masalah-masalah yang timbul karena sasaran yang saling bertentangan tidak diatasi dengan baik tahap ini sering kembali menjadi situasi prakonflik.

Konflik dapat dikelola melalui tiga dasar penyelesaian (Condliffe, 1991 sebagaimana dikutip Sardjono, 2004), yaitu: (1) langsung antar pihak yang bersengketa (one-toone), dimana masing-masing pihak yang bersengketa bertindak untuk menyelesaikannya sendiri; (2) mewakilkan kepada pihak lain (representational), dimana pihak-pihak yang bersengketa diwakili pihak lain seolperti pengacara, teman kolega, dan asosiasi resmi; dan (3) menggunakan pihak ketiga berdasarkan inisiatif mereka sendiri atau atas pemintaan kedua belah pihak yang bersengketa atau karena hak yang dimilikinya. Condliffe (1991) sebagaimana dikutip Sardjono (2004), juga mengajukan delapan prosedur umum dalam rangka penyelesaian konflik, yaitu: Lumping it, Avoidance or exit, Coersion, Negotiation, Conciliation, Mediaton, Arbitration, dan Adjudication. Dari kedelapan prosedur umum penyelesaian konflik di atas, hanya butir negoisasi, konsiliasi dan mediasi yang merupakan penyelesaian konflik di luar pengadilan yang dipandang kondusif. Hal ini dikarenakan ketiganya mengandung unsur win-win solution yang sifatnya lebih langgeng. Sebagaimana yang disinggung oleh Sardjono (2004), bahwa penyelesaian konflik melalui jalur formal legal yang akan diperoleh adalah 'menang-kalah' atau 'gembira-kecewa'. Oleh karena itu, cara ini hanya akan ditempuh bila: (1) upaya penyelesaian melalui perundingan menemui jalan buntu; (2) tingkat pelanggaran atau tuntutan telah melampaui batas toleransi; dan (3) merupakan kebiasaan dan kepentingan publik. Fuad dan Maskanah (2000) menyebutkan bahwa khusus mengenai konflik yang terjadi dalam pengelolaan sumberdaya hutan, UU No.41 Tahun 1999 tentang Kehutanan mengatur bahwa penyelesaian sengketa kehutanan dapat ditempuh melalui pengadilan atau di luar pengadilan berdasarkan pilihan secara sukarela para pihak yang bersengketa (Pasal 74, ayat 1). Penyelesaian sengketa kehutanan di luar pengadilan dimaksudkan untuk mencapai kesepakatan mengenai pengambilan suatu hak, besarnya ganti rugi, dan/atau mengenai bentuk tindakan tertentu yang harus dilakukan untuk memulihkan fungsi hutan (Pasal 75).

\section{GAMBARAN UMUM KASEPUHAN SINAR RESMI}

Komunitas adat Banten Kidul adalah suatu komunitas yang dalam kesehariannya menjalankan sosio-budaya tradisional yang mengacu pada karakteristik budaya Sunda pada abad ke-18 (Asep, 2000 sebagaimana dikutip Hanafi et al., 2004). Kasepuhan Sinar Resmi merupakan satu dari sebelas Kasepuhan yang berada di Wilayah Banten Kidul (Banten Selatan) dan merupakan bagian dari komunitas adat Banten Kidul. Wilayah Kasepuhan Sinar Resmi juga berbatasan dengan kawasan Taman Nasional Gunung Halimun-Salak. Pusat Kasepuhan ini terletak di Kampung Sinar Resmi, Desa Sirnaresmi, Kecamatan Cisolok, Kabupaten Sukabumi, Jawa Barat dan memiliki jarak $23 \mathrm{Km}$ ke Kecamatan Cisolok dan 33 $\mathrm{Km}$ ke Kabupaten Sukabumi. Kampung Sinar Resmi berada pada ketinggian 600-1200 meter di atas permukaan laut dan berada di lereng selatan Gunung Halimun. Adapun batas wilayah Kampung Sinar Resmi adalah sebagai berikut:

\section{Barat : Desa Cicadas \\ Timur : Kampung Cikaret \\ Utara : Sungai Cibareno \\ Selatan : Kampung Cibombong}

Menurut Ketua Adat, Abah ASN (44 tahun) batas-batas Kasepuhan sulit ditentukan secara administratif, karena tersebarnya masyarakat adat Kasepuhan (incu putu) di wilayah Gunung Halimun. Bahkan masih menurut Abah, seluruh kawasan Gunung Halimun adalah wilayah adat Komunitas Adat Banten Kidul, dimana Kasepuhan Sinar Resmi adalah salah satu bagiannya.

Dilihat dari segi religi, seluruh masyarakat adat Kasepuhan mengaku beragama Islam, meskipun dalam beberapa hal masih mempercayai hal-hal yang bersifat ghaib (Animisme). Menurut tokoh adat kampung, Wa UGS (64 tahun) mereka mengikuti tata cara ibadah yang dilakukan oleh Rasul, dengan istilah Slampangan dika Gusti Rasul. Menurut Rosdiana (1994) sebagaimana dikutip oleh Kurniawan (2002) masyarakat adat Kasepuhan mempunyai kepercayaan yang kuat terhadap kekuatan alam yang dikuasai oleh para leluhur mereka. Hal ini ditunjukkan dengan masih adanya ritual-ritual adat yang diwariskan leluhur dalam setiap kegiatan kemasyarakatan, seperti membakar kemenyan dengan diiringi dengan mantera-mantera yang dilafalkan dalam bahasa Sunda yang ditujukan untuk Gusti Nu Kuasa (Tuhan Yang Maha Kuasa) dan para leluhur. Bagi mereka, adat dan kepercayaan itu merupakan pedoman hidup utama dalam menjalankan kehidupan. Menurut sejarah, masyarakat adat Kasepuhan merupakan keturunan dari para sisa pasukan Kerajaan Padjajaran yang melarikan diri ke wilayah Gunung Halimun ketika terjadi penyerangan oleh Kerajaan Islam. Oleh sebab itu, masyarakat adat Kasepuhan mewariskan adat dan budaya dari Kerajaan Padjajaran, salah satunya adalah Bahasa Sunda. Bahasa Sunda digunakan dalam percakapan 
sehari-hari masyarakatnya. Selain itu, bahasa Sunda pun digunakan dalam berkomunikasi dengan para leluhur dan dalam ritual-ritual adat.

Masyarakat adat Kasepuhan Sinar Resmi bertahan hidup melalui pertanian ladang dan sawah dengan sistem subsisten. Pertanian ladang (huma) dan sawah masyarakat adat Kasepuhan hanya dilakukan setahun sekali pada bulan September hingga bulan Oktober. Hal ini didasarkan pada kepercayaan masyarakat yang diwariskan oleh leluhur mereka, yang menganggap bahwa tidak akan berhasil jika menanam padi lebih dari satu kali dalam setahun. Selain itu, anggapan ini didasarkan pada prinsip Ibu Bumi yang menganggap bumi (tanah) sebagai Ibu dan pada hakikatnya seorang ibu hanya dapat melahirkan setahun sekali. Peraturan adat melarang masyarakat untuk memperjualbelikan beras sebagai makanan pokok, dan hasil olahan lainnya.

Tabel 1. Tahap-tahap Kegiatan Pertanian Ladang

\begin{tabular}{|c|c|c|}
\hline Kegiatan & $\begin{array}{c}\text { Bulan } \\
\text { (Sistem Kalender } \\
\text { Islam) }\end{array}$ & $\begin{array}{c}\text { Pelaksana } \\
\text { *) }\end{array}$ \\
\hline $\begin{array}{l}\text { Narawas } \\
\text { (menBapal: Toui lokasi yang alan dijadikan lahan } \\
\text { huma) }\end{array}$ & Jumadil amal & $\mathrm{Lk}$ \\
\hline $\begin{array}{l}\text { Nyacar } \\
\text { (membersihkan lahan, biasanya selama } 1 \text { minggu } \\
\text { getelah itu di keringlan salama } 15 \text { hari }-1 \text { bulan) }\end{array}$ & Jumadil awal & $\mathrm{Lk}, \mathrm{Pr}, \mathrm{P}$ \\
\hline $\begin{array}{l}\text { Ngahuru } \\
\text { (membalkar semak kering untuk dijadikan pupulk) }\end{array}$ & Jumadil alkhir & Lk \\
\hline $\begin{array}{l}\text { Ngerukan } \\
\text { (mengumpulkan sisa-sias yang belum terbakar) }\end{array}$ & Jumadil alkhir & Lk, $\mathrm{Pr}, \mathrm{P}$ \\
\hline $\begin{array}{l}\text { Ngaduruk } \\
\text { (membakar sisa-sisanya) }\end{array}$ & Jumadil alkhir & $\mathrm{Lk}, \mathrm{Pr}$ \\
\hline $\begin{array}{l}\text { Nyara } \\
\text { (meremahkan tanah) }\end{array}$ & Jumadil alkhir & $\mathrm{Lk}, \mathrm{Pr}, \mathrm{P}$ \\
\hline $\begin{array}{l}\text { Ngaseuk } \\
\text { (penanaman bibit padi dengan menggunakan } \\
\text { tonghat atan asoukh) }\end{array}$ & Rajab & $\mathrm{Lk}, \mathrm{Pr}, \mathrm{P}$ \\
\hline $\begin{array}{l}\text { Ngored } \\
\text { (menyiangi numput) }\end{array}$ & Ruwah & $\mathrm{Lk}, \mathrm{Pr}, \mathrm{P}$ \\
\hline $\begin{array}{l}\text { Mipit Dibuat } \\
\text { (memotong padi/ pansan) }\end{array}$ & Haji & Lk, Pr \\
\hline $\begin{array}{l}\text { Ngadamel lantayan } \\
\text { (membuat tempat menjemur padi) }\end{array}$ & Haji & Lk: \\
\hline $\begin{array}{l}\text { Ngalantaykeun } \\
\text { (proses merjemur padi pada lantayan) }\end{array}$ & Haji & Lk, Pr \\
\hline $\begin{array}{l}\text { Mocong } \\
\text { (mengikat padi yang kering) }\end{array}$ & Muharam & $\mathrm{Lk}, \mathrm{Pr}, \mathrm{P}$ \\
\hline $\begin{array}{l}\text { Ngunjal } \\
\text { (dianghut ke lumbung padi) }\end{array}$ & Muharam & $\mathrm{Lk}$ \\
\hline $\begin{array}{l}\text { Ngaleuitkeun } \\
\text { (memaglkan ka lumbung) }\end{array}$ & Muharam & Lk, $\mathrm{Pr}$ \\
\hline $\begin{array}{l}\text { Ngeuleupkeun } \\
\text { (dirapilkan) }\end{array}$ & Muharam & $\mathrm{Lk}$ \\
\hline $\begin{array}{l}\text { Ngadieukeun indung pare } \\
\text { (meryimpan padi di dalam lecit) }\end{array}$ & Muharam & Lk: \\
\hline $\begin{array}{l}\text { Selametan } \\
\text { (ampih pare) }\end{array}$ & Muharam & $\mathrm{Lk}, \mathrm{Pr}, \mathrm{P}$ \\
\hline
\end{tabular}

Dari 17 prosesi di atas, ada enam kegiatan utama yang harus dilakukan antara lain:

- Ngaseuk merupakan kegiatan menanam padi dengan memasukkan benih ke dalam lubang dengan menggunakan aseuk (tongkat).

- Beberes Mager: ritual untuk menjaga padi dari serangan hama. Kegiatan ini dilakukan oleh pemburu di ladang Abah (ladang milik Kasepuhan) dengan membaca doa. Kegiatan ini dilaksanakan sekitar bulan Muharam.
- Ngarawunan : ritual untuk meminta isi padi agar tumbuh dengan subur, sempurna dan tidak ada gangguan. Kegiatan ini dilakukan oleh semua incu putu untuk meminta doa kepada abah melalui bagian pamakayaan. Ngasrawunan dilakukan setelah padi berumur tiga bulan sampai empat bulan.

- Mipit: kegiatan memanen padi yang dilakukan lebih dulu oleh Abah sebagai pertBapak/Ibu masuknya musim panen.

- $\quad$ Nutu: kegiatan menumbuk padi pertama hasil panen.

- Nganyaran: memasak nasi menggunakan padi hasil panen pertama, dua bulan setelah masa panen.

Masyarakat adat Kasepuhan memiliki ketergantungan yang tinggi terhadap hutan. Mereka menganggap hutan sebagai tempat untuk memenuhi kebutuhan hidup seharihari. Hutan yang dimanfaatkan oleh masyarakat adat Kasepuhan adalah hutan titipan. Hasil yang dimanfaatkan berupa kayu-kayuan dan bambu untuk membuat rumah, leuit, sarana ibadah, dan lainnya, nipah dan kirai untuk membuat atap rumah, buah-buahan, madu hutan, rotan untuk membuat kerajinan-kerajinan dan peralatan rumah tangga, dan tanaman obat-obatan.

\section{Tabel 2. Penggunaan LahanMasyarakatKasepuhan SinarResmi di Desa Sirna Resmi}

\begin{tabular}{|l|l|l|}
\hline \multicolumn{1}{|c|}{ Penggunaan lahan } & \multicolumn{1}{|c|}{ Zona di Kasepuhan } & Luas $(\mathrm{Ha})$ \\
\hline Pemukiman & Hutan bukaan (lerweung garapan) & 78,18 \\
\hline Sawah & Hutan bukaan (lewweung garapan) & 559,98 \\
\hline Perkebunan & Hutan bukaan (lewweung garapan) & 303,4 \\
\hline Tanah kuburan & Hutan bukaan (lerweung garapan) & 7.00 \\
\hline Hutan adat & Hutan titipan (lerweung titipan) & $1.013,00$ \\
\hline Hutan adat & Hutan yang dilindungi (leweung tutupan) & $2.948,48$ \\
\hline Total luas desa & & $4.906,04$ \\
\hline
\end{tabular}

Sumber: Suganda, 2009

Sumberdaya alam yang dimiliki oleh masyarakat adat Kasepuhan dianggap sebagai karunia Tuhan Yang Maha Esa dan titipan dari para leluhur mereka. Oleh karena itu, mereka wajib untuk menjaga keutuhan dan mempergunakan sebaik-baiknya untuk memenuhi kebutuhan hidup mereka saat ini hingga generasi mendatang. Sebagai lahan titipan para leluhur, seluruh sumberdaya alam ini diklaim sebagai milik adat dan bersifat komunal. Hanya boleh dipergunakan dan dimanfaatkan untuk hidup, namun tidak boleh untuk dijual dan dimiliki secara individual. Pengaturan penggunaan dan pengelolaan sumberdaya alam di Kasepuhan, diatur oleh seorang Abah sebagai pemimpin adat. Terkait dengan keberadaan taman nasional sebagai kawasan konservasi, institusi pengelola di Indonesia mencakup unsur hak kepemilikan, batas wilayah kewenangan dan aturan keterwakilan. Hak kepemilikan taman nasional, sesuai dengan UUD 1945 Pasal 33 dan UU No. 5 Tahun 1967 mengenai Ketentuan-Ketentuan Pokok Kehutanan adalah milik negara (state property). Menurut pasal 34 UU No. 5 Tahun 1990 mengenai Konservasi Sumberdaya Alam dan Ekosistemnya, pengelolaan taman nasional dilaksanakan oleh pemerintah, dalam hal ini oleh Kementerian Kehutanan. Kawasan konservasi taman nasional, memiliki lokasi 
yang berdekatan, bahkan bertumpang tindih dengan wilayah adat Kasepuhan. Dalam kasus Kasepuhan Sinar Resmi, wilayah adat yang tumpang tindih dengan kawasan taman nasional pada zona rimba dan zona rehabilitasi adalah leuweung tutupan, leuweung titipan dan leuweung Bukaan.

\section{PEMBAHASAN}

\section{Sejarah Konflik di Taman Nasional Gunung Halimun Salak}

Konflik kehutanan di kawasan Gunung Halimun dimulai sejak tahun 1970-an, ketika hak pengelolaan hutan dipegang oleh Perhutani. Saat itu terjadi tumpang tindih antara hutan-hutan milik Perhutani dan hutan adat milik Kasepuhan. Pada tahun 1974, kawasan Kasepuhan dengan dipimpin oleh Ki Ardjo berpindah ke daerah Ciganas, Desa Sirna Rasa. Akan tetapi kawasan ini sudah termasuk dalam kawasan Perhutani. Persoalan mulai terjadi saat aparat keamanan melihat incu putu (masyarakat adat) Kasepuhan mulai membuka huma dengan membabat bukit-bukit di daerah penyangga. Namun hal ini tidak menjadi persoalan yang berkepanjangan, mengingat saat itu, hubungan antara pihak Kasepuhan dengan Perhutani dan pemerintah daerah setempat terjalin dengan baik. Keributan mengenai pemukiman dan perladangan yang berpindah-pindah dimulai sejak Kasepuhan dipimpin oleh Abah Anom pada tahun 1983 yang memindahkan Kasepuhan ke Cipta Rasa yang termasuk dalam blok Datar Putat. Abah Anom dianggap telah menyerobot lahan milik Perhutani tanpa izin dan membuka areal yang tadinya merupakan hutan utuh. Permasalahan diselesaikan dengan menyelenggarakan musyawarah yang mempertemukan pihak Kasepuhan dengan Perhutani. Hasilnya, masyarakat Kasepuhan masih diperbolehkan untuk tetap tinggal di wilayah adatnya sesuai dengan wangsit dari karuhun yang belum 'memerintahkan' untuk pindah. Namun, Abah Anom harus menukarkan tanahnya seluas hampir $16.000 \mathrm{~m}^{2}$ di Ciarca untuk mengganti wilayah Perhutani di Cipta Rasa (blok Datar Putat). Tapi pihak kehutanan mengizinkan incu putu untuk menggarap wilayah di Ciarca tersebut dengan sistem tumpang sari.

Permasalahan yang terjadi dengan Perhutani tidak hanya mengenai persoalan lahan. Ada permasalahan lain yang terjadi. Menurut Wa UGS, permasalahan muncul ketika Perhutani menjadikan kawasan hutan titipan Kasepuhan sebagai kawasan hutan produksi. Padahal menurut peraturan adat Kasepuhan, di dalam kawasan hutan titipan (leuweung titipan) tidak boleh ada kegiatan ekonomi termasuk untuk produksi massal, bertentangan dengan fungsi hutan produksi Perhutani yang memfungsikan kawasan hutan tersebut untuk kegiatan ekonomi. Namun, permasalahan ini tidak sampai menimbulkan konflik yang keras, karena bisa diselesaikan dengan baik, dan Perhutani memindahkan lokasi hutan produksinya ke luar wilayah hutan titipan. Selain itu, pihak Perhutani juga masih mengizinkan incu putu (masyarakat adat Kasepuhan) untuk menggarap hutan produksi dengan sistem tumpang sari.

Pemerintah mengeluarkan SK. Menteri Kehutanan No.282 tahun 1992 yang mengacu pada UU pokok Kehutanan No.5/1967 dan UU Konservasi dan
Sumberdaya Hayati No.5/1990 yang menetapkan kawasan Gunung Halimun seluas 40.000 hektar sebagai kawasan taman nasional di bawah pengelolaan sementara Balai Taman Nasional (BTN) Gunung Gede Pangrango dengan nama Taman Nasional Gunung Halimun ${ }^{1}$. Sejak berlakunya surat keputusan tersebut, pihak balai taman nasional mulai membatasi segala kegiatan pendayagunaan oleh manusia, termasuk di dalamnya pelarangan pengambilan kayu bakar, tanaman untuk obat-obatan, dan hasil hutan lainnya oleh masyarakat sekitar kawasan. Selain itu, pengusiran secara halus pun dilakukan kepada masyarakat yang wilayah pemukimannya masuk dalam zona-zona taman nasional. Hal ini dialami oleh masyarakat adat Kasepuhan Cipta Gelar, di mana seluruh kawasan adat masuk ke dalam kawasan taman nasional. Lain halnya dengan Kasepuhan Cipta Gelar, yang seluruh kawasan adatnya masuk ke dalam kawasan taman nasional, kawasan Kasepuhan Sinar Resmi yang masuk dalam kawasan taman nasional, zona rimba dan zona rehabilitasi, 'hanya' kawasan lahan garapan warga saja, termasuk di dalamnya talun, huma dan sawah.

Keadaan bertambah parah saat pemerintah mengeluarkan SK Menteri Kehutanan No. 175/kpts-II/ 2003, tentang perluasan kawasan Taman Nasional Gunung HalimunSalak menjadi 113.357 hektar. Banyak lahan garapan maupun pemukiman masyarakat, baik masyarakat adat maupun masyarakat lokal yang akhirnya masuk dalam kawasan konservasi sehingga kegiatan pertanian pun menjadi terbatas. Pengelolaan Taman Nasional Gunung Halimun-Salak dilakukan dengan sistem zonasi, sesuai dengan Peraturan Menteri Kehutanan No.56 Tahun 2006, mengenai Pedoman Zonasi Taman Nasional. Zonasizonasi tersebut adalah zona inti, zona rimba, zona pemanfaatan, dan zona lain sesuai kebutuhan.

Masyarakat adat sendiri menganggap bahwa sistem zonasi yang dibuat oleh taman nasional sama artinya dengan sistem pengelolaan hutan secara adat, terutama untuk zona inti dan hutan tutupan Kasepuhan. Namun, permasalahannya adalah ketika kebun, ladang, sawah dan pemukiman masyarakat diklaim sebagai zona rimba dan zona rehabilitasi taman nasional. Masyarakat adat tidak boleh tinggal dan berada di kawasan zona rimba dan zona rehabilitasi karena zona rimba berfungsi sebagai kawasan yang mendukung zona inti dan zona rehabilitasi berfungsi untuk pemulihan ekosistem hutan. Pentingnya kawasan kebun, sawah, dan ladang masyarakat adat dalam memenuhi kebutuhan hidup, membuat masyarakat tetap berada di sana dan mengolah lahan seperti biasanya walaupun harus dengan cara "sembunyi-sembunyi" karena takut ditangkap.

Pada tahun 2007 terjadi juga penangkapan terhadap warga Kasepuhan yang tinggal di Kampung Cibalandongan karena mengambil kayu dari kebun miliknya sendiri, karena dianggap telah merusak kawasan taman nasional. Warga tersebut ditahan selama 10 bulan penjara. Setelah itu, ada pula warga Kampung Lebak Nangka pada tahun 2008 juga ditangkap karena mengambil kayu di kebun sendiri. Padahal sebelum adanya taman nasional, lahan kebun termasuk pohon yang di dalamnya adalah milik

\footnotetext{
${ }^{1}$ www.tnhalimun.go.id [29 November 2010]
} 
warga, karena sejak wilayah tersebut masih dimiliki oleh Perhutani, warga boleh menggarap lahan tersebut dan menanam pohon kayu-kayuan dengan sistem tumpang sari.

Pihak-pihak yang terlibat dalam konflik di Taman Nasional Gunung Halimun-Salak adalah Perhutani yang kemudian digantikan oleh Balai Taman Nasional Gunung Halimun-Salak melalui SK. Menhut No. 175 Tahun 2003, serta masyarakat adat Kasepuhan Sinar Resmi.

\section{Sumber-Sumber Konflik Sumberdaya Alam di Taman Nasional Gunung Halimun-Salak}

Penyebab konflik kehutanan yang terjadi di Taman Nasional Gunung Halimun-Salak disebabkan oleh empat sumber perbedaan, yaitu: perbedaan persepsi, kepentingan, tatanilai, dan akuan hak kepemilikan.

Perbedaan persepsi terjadi ketika pihak taman nasional menganggap masyarakat sebagai perambah hutan dan pelaku illegal logging. Sedangkan masyarakat adat Kasepuhan menganggap pihak taman nasional telah menyerobot lahan garapan masyarakat untuk dijadikan taman nasional.

Perbedaan dalam menilai fungsi hutan terjadi ketika pihak taman nasional menganggap kawasan Gunung Halimun sebagai kawasan hutan yang perlu dijaga kelestariannya karena merupakan daerah resapan air dan memiliki keanekaragaman yang tinggi, sehingga diperlukan upaya konservasi. Sedangkan masyarakat adat Kasepuhan menilai hutan sebagai tempat pemenuhan kebutuhan hidup sehari-hari mereka dan sebagai tempat spiritual yang dipercaya memiliki benda-benda pusaka.

Perbedaan kepentingan terjadi ketika pihak taman nasional memiliki kepentingan konservasi pada kawasan Gunung Halimun dan masyarakat adat memiliki kepentingan terhadap Gunung Halimun sebagai ruang hidup.

Tabel 3. Peta Kepentingan atas Hutanbagi Pihak-pihak yang Terlibat Konflik

\begin{tabular}{|c|c|}
\hline Pihak-pihak yang Terlibat Konflik & Kepentingan atas hutan \\
\hline Masyarakat Adat & $\begin{array}{l}\text { Masyarakat adat Kasepuhan memiliki } \\
\text { ketergantungan yang tinggi terhadap hutan. } \\
\text { Mereka menganggap hutan sebagai tempat } \\
\text { untuk memenuhi kebutuhan hidup sehari- } \\
\text { hari. Selain itu, hutan pun memiliki nilai } \\
\text { spiritual yang tinggi. Kawasan hutan titipan } \\
\text { yang merupakan hutan titipan leluhur } \\
\text { dipercaya menyimpan benda-benda pusaka } \\
\text { milik leluhur yang harus dijaga. Selain itu, } \\
\text { kawasan hutan titipan juga merupakan daerah } \\
\text { resapan air (leuweung sirah cai), dimana air } \\
\text { merupakan kebutuhan pokok manusia. }\end{array}$ \\
\hline $\begin{array}{l}\text { Taman Nasional Gunung Halimun- } \\
\text { Salak }\end{array}$ & $\begin{array}{l}\text { kawasan hutan Gunung Halimun dan Gunung } \\
\text { Salak merupakan kesatuan hamparan hutan } \\
\text { dataran rendah dan pegunungan yang } \\
\text { mempunyai keanekaragaman hayati yang } \\
\text { tinggi, sumber mata air bagi kepentingan } \\
\text { kehidupan masyarakat disekitarnya yang } \\
\text { perlu dilindungi dan dilestarikan, melalui } \\
\text { upaya konservasi. }\end{array}$ \\
\hline
\end{tabular}

Sumber: diolah dari data primer, 2010, dan www.tnhalimun.go.id

Masing-masing pihak memiliki kepentingan yang berbeda atas obyek yang sama yaitu hutan. Masyarakat adat Kasepuhan memiliki ketergantungan yang tinggi terhadap hutan untuk memenuhi kebutuhan hidupnya, sehingga mustahil bagi mereka untuk meninggalkan dan lepas dari hutan. Taman Nasional Gunung Halimun-Salak, beranggapan Gunung Halimun dan Gunung Salak perlu untuk di konservasi karena memiliki keanekaragaman yang tinggi dan perlu dilestarikan. Kepentingankepentingan yang berbeda dan masing-masing pihak merasa bahwa kepentingannya yang harus didahulukan membuat pihak-pihak tersebut bentrok, karena tidak ada yang mau mengorbankan kepentingannya.

Perbedaan dalam akuan hak kepemilikan (klaim), terjadi ketika pihak taman nasional menganggap bahwa kawasan Taman Nasional Gunung Halimun-Salak sebagai milik Negara karena tidak terbebani hak atas tanah, namun masyarakat adat menganggap bahwa kawasan Gunung Halimun adalah milik adat, karena sudah diwariskan oleh leluhur untuk anak-cucu mereka.

Namun, permasalahan utama dalam konflik di Taman Nasional Gunung Halimun-Salak terletak pada Perbedaan dalam akuan hak kepemilikan (klaim), terjadi ketika pihak taman nasional menganggap bahwa kawasan Taman Nasional Gunung Halimun-Salak sebagai milik negara karena tidak terbebani hak atas tanah, sedangkan masyarakat adat menganggap bahwa kawasan Gunung Halimun adalah milik adat, karena sudah diwariskan oleh leluhur untuk anak-cucu mereka.

\section{Bentuk-bentuk Penyelesaian Konflik yang Telah Dilakukan}

Konflik di Taman Nasional Gunung Halimun-Salak bukan tidak pernah berusaha untuk diselesaikan. Telah ada upaya-upaya yang dilakukan baik oleh pihak pemerintah maupun pihak Kasepuhan sendiri untuk meredam konflik yang terjadi.Beberapa upaya yang telah dilakukan untuk menyelesaikan konflik kehutanan Halimun adalah sebagai berikut:

1. pihak Taman Nasional Gunung Halimun-Salak menawarkan kepada Kasepuhan untuk menjadikan wilayah adat Kasepuhan, khususnya Kasepuhan Cipta Gelar yang wilayah berada pada enclave taman nasional, untuk dijadikan zona khusus budaya

2. pihak Taman Nasional Gunung Halimun-Salak juga pernah mengajukan berkas pengelolaan Gunung Halimun kepada Kasepuhan, namun pihak Kasepuhan menolak, karena seharusnya usulan pengelolaan hutan harus berasal dari pihak Kasepuhan yang lebih mengetahui kebutuhan masyarakatnya.

3. saat ini, masyarakat Kasepuhan Adat Banten Kidul khususnya yang berada di Kabupaten Sukabumi (Kasepuhan Sinar Resmi, Cipta Gelar dan Cipta Mulya) sedang mengajukan peraturan daerah mengenai pengakuan hak tanah adat kepada Pemerintah Daerah. Berkasnya sudah sampai pada tingkat Badan Legislatif Daerah pada bulan September 2010, namun masih dalam proses karena pemetaan wilayah adat untuk ketiga Kasepuhan tersebut belum dilaksanakan

Upaya yang telah dilakukan adalah negosiasi, namun tidak sampai pada kesepakatan. Diperlukan proses 
mediasi dan mediator untuk mengakomodasi keinginan pihak-pihak yang berkonflik.

\section{KESIMPULAN}

Sejarah konflik sumberdaya alam di kawasan Taman Nasional Gunung Halimun-Salak dimulai ketika kawasan Gunung Halimun dikelola oleh Perhutani pada tahun 1970-an. Saat itu, pihak Kasepuhan dianggap telah menyerobot lahan Perhutani dengan membuka hutan utuh untuk ladang dan sawah milik warga. Selain masalah penyerobotan lahan, konflik dengan Perhutani pun terjadi ketika ada tumpang tindih antara hutan adat dan hutan produksi milik Perhutani. Konflik semakin parah ketika pengelolaan Gunung Halimun dialihkan ke Balai Taman Nasional Gunung Halimun-Salak. Wilayah pemukiman dan pertanian warga diklaim sebagai zona rimba dan zona rehabilitasi taman nasional. Pihak taman nasional menakuti-nakuti akan mengusir warga dari tempat tinggalnya. Selain itu, terjadi penangkapan terhadap warga yang sedang berada di kebunnya, dan dituduh sebagai perambah hutan dan melakukan illegal logging. Pihak taman nasional pun memasang papan pengumuman mengenai pelarangan masuk kawasan konservasi di kebun dan di depan rumah warga.

Pihak-pihak yang terlibat dalam konflik di Taman Nasional Gunung Halimun-Salak adalah Perhutani yang kemudian digantikan oleh Balai Taman Nasional Gunung Halimun-Salak melalui SK. Menhut No. 175 Tahun 2003, serta masyarakat adat Kasepuhan Sinar Resmi.

Penyebab konflik kehutanan yang terjadi di Taman Nasional Gunung Halimun-Salak disebabkan oleh empat sumber perbedaan, yaitu: perbedaan persepsi, kepentingan, tatanilai, dan akuan hak kepemilikan. Namun, permasalahan utama dalam konflik di Taman Nasional Gunung Halimun-Salak terletak pada Perbedaan dalam akuan hak kepemilikan, terjadi ketika pihak taman nasional menganggap bahwa kawasan Taman Nasional Gunung Halimun-Salak sebagai milik Negara karena tidak terbebani hak atas tanah, sedangkan masyarakat adat menganggap bahwa kawasan Gunung Halimun adalah milik adat, karena sudah diwariskan oleh leluhur untuk anak-cucu mereka.

Konflik di Taman Nasional Gunung Halimun-Salak bukan tidak pernah berusaha untuk diselesaikan. Telah ada upaya-upaya yang dilakukan baik oleh pihak pemerintah maupun pihak Kasepuhan sendiri untuk meredam konflik yang terjadi. Upaya yang telah dilakukan adalah negosiasi, namun tidak sampai pada kesepakatan. Diperlukan proses mediasi dan mediator untuk mengakomodasi keinginan pihak-pihak yang berkonflik.

\section{DAFTAR PUSTAKA}

Budimanta, A. 2007. Kekuasaan dan Penguasaan Sumber Daya Alam. Jakarta. ICSD.

Fisher, S.; D. I. Abdi; J. Ludin; R. Smith; S. Williams \& S. Williams. 2001. Mengelola Konflik: Keterampilan dan Strategi untuk Bertindak.
S.N. Kartika Sari; M.D. Tapilatu; R. Maharani \& D.N. Rini (Penterjemah). Terjemahan. Jakarta. The British Council.

Fuad, F.H \& Siti Maskanah. 2000. Inovasi Penyelesaian Sengketa Pengelolaan Sumber Daya Hutan. Bogor. Pustaka LATIN.

Hanafi, I; Nia R. \& Budi N. 2004. Nyoreang alam Ka Tukang Nyawang Anu Bakal Datang: Penelusuran Pergulatan di Kawasan Halimun, Jawa Barat-Banten. Bogor. RMI.

Ilham, M. 2006. Analisa Konflik Pengelolaan Sumber Daya Alam Masyarakat Desa Sekitar Hutan (Studi Kasus Masyarakat Desa Curugbitung, Kecamatan Nanggung, Kabupaten Bogor, Propinsi Jawa Barat). Bogor. IPB.

Menteri Kehutanan RI. 2006. Peraturan Menteri Kehutanan Nomor 56 Tahun 2006 tentang Zonasi Taman Nasional.

2003. Surat Keputusan Menteri Kehutanan Nomor 175 Tahun 2003 tentang Penunjukan Kawasan Hutan Halimun dan Salak sebagai Taman Nasional Gunung Halimun-Salak.

Menteri/Sekretaris Negara. 1990. Undang Undang No. 5 Tahun 1990 tentang Konservasi Sumberdaya Alam Hayati Dan Ekosistemnya

Sardjono, M. A. 2004. Mosaik Sosiologis Kehutanan: Masyarakat Lokal, Politikus dan Kelestarian Sumberdaya. Jogjakarta. Debut Press.

Sitorus, M. T. Felix. 1998. Metode Penelitian Kualitatif: Suatu Perkenalan. Bogor. Dokumen Ilmu-Ilmu Sosial.

Suganda, Ugis. 2009. The Cipta Gelar Kasepuhan Indigenous Community, West Java: Developing a bargaining position over costumary forest dalam Kleden E. O.; Liz C. \& Yuyun Indradi. 2009. Forest for the Future: Indigenous Forest Management in a Changing World. AMAN-DTE.

Tadjudin, D. 1999. Model Kelembagaan Masayarakat dalam Pengelolaan Hutan Alam Produksi. Jurnal Seri Kajian Komuniti Forestri Seri 3 Tahun 2. Bogor. LATIN.

Tadjudin, D. 2000. Manajemen Kolaborasi. Bogor. Pustaka LATIN.

[TNGH-S] Taman Nasional Gunung Halimun-Salak. Overview. $\quad$ http://tnhalimun.go.id. $\quad[29$ November 2010]

Ulfah, S.M. 2007. Identifikasi Konflik dalam Pengelolaan Wisata di Kawasan Gunung Salak Endah Kecamatan Pamijahan Kabupaten Bogor. Bogor. IPB. 